UCRL-53252

Distribution Category UC-66d

UCRL -53252

DE82 014954

\title{
A Cementation Process for Minerals Recovery from Salton Sea Geothermal Brines
}

\author{
Arturo Maimoni \\ Manuscript Date: January 26, 1982

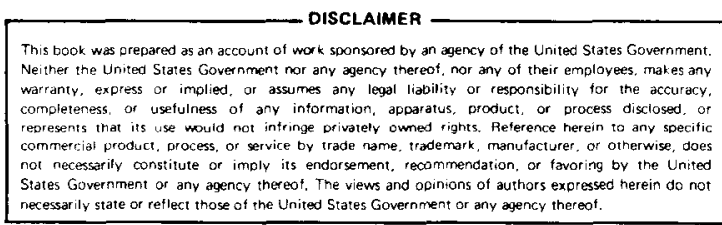

LAWRENCE LIVERMORE LABORATORY University of California $\bullet$ Livermore, California $\bullet 94550 \backsim$ 


\section{DISCLAIMER}

This report was prepared as an account of work sponsored by an agency of the United States Government. Neither the United States Government nor any agency Thereof, nor any of their employees, makes any warranty, express or implied, or assumes any legal liability or responsibility for the accuracy, completeness, or usefulness of any information, apparatus, product, or process disclosed, or represents that its use would not infringe privately owned rights. Reference herein to any specific commercial product, process, or service by trade name, trademark, manufacturer, or otherwise does not necessarily constitute or imply its endorsement, recommendation, or favoring by the United States Government or any agency thereof. The views and opinions of authors expressed herein do not necessarily state or reflect those of the United States Government or any agency thereof. 


\section{DISCLAIMER}

Portions of this document may be illegible in electronic image products. Images are produced from the best available original document. 


\section{Contents}

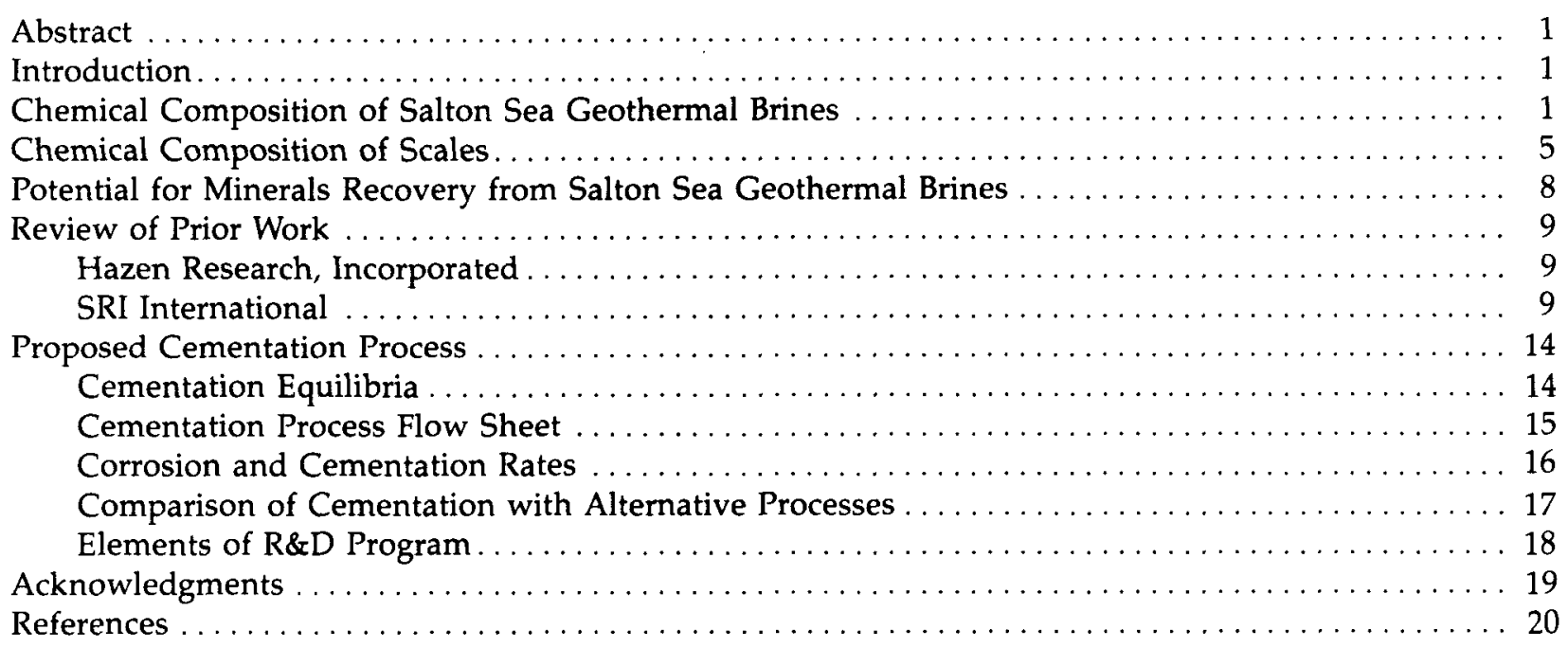




\title{
A Cementation Process for Minerals Recovery from Salton Sea Geothermal Brines
}

\begin{abstract}
The potential for minerals recovery from a 1000-MWe combined geothermal power and minerals recovery plant in the Salton Sea is examined. While the possible value of minerals recovered would substantially exceed the revenue from power production, information is insufficient to carry out a detailed economic analysis. The recovery of precious metals-silver, gold, and platinum-is the most important factor in determining the economics of a minerals recovery plant; however, the precious metals content of the brines is not certain. Such a power plant could recover $14-31 \%$ of the U.S. demand for manganese and substantial amounts of zinc and lead. Previous work on minerals extraction from Salton Sea brines is also reviewed and a new process, based on a fluidized-bed cementation reaction with metallic iron, is proposed. This process would recover the precious metals, lead, and tin present in the brines.
\end{abstract}

\section{Introduction}

Brines from various sources are being used worldwide as sources for a variety of minerals. While the potential use of geothermal brines for simultaneous energy and minerals production has not been explored in detail, potassium chloride has been recovered from salts in the evaporation ponds at the Cerro Prieto, Mexico, geothermal plant $^{1}$ and the U.S. Bureau of Mines has sponsored two experimental programs on minerals extraction from brines in the Salton Sea Geothermal Field, California.

The brines in the Salton Sea KGRA (Known Geothermal Resource Area), also called Niland brines, are particularly interesting for combined energy and minerals recovery because of their high temperature, high salinity, and the fact that some processing would be required for brine reinjection regardless of minerals recovery.

The amounts of electrical energy recoverable from the Salton Sea have been estimated to lie between 1100 and 8700 MWe for 20 years. ${ }^{2}$ For a combined geothermal power-minerals recovery plant, the revenue from the minerals recovered can substantially exceed the revenue from power production. A 1000-MWe power plant could recover $14-31 \%$ of the U.S. demand for manganese, ${ }^{3}$ together with significant quantities of zinc and lead. The potential for lithium recovery is very large; one such 1000-MWe plant could recover between 31 and 65 thousand metric tons of lithium per year (metal equivalent), compared to the 1980 total world sales of about 7.2 thousand metric tons. ${ }^{4}$ The value of minerals potentially recoverable cannot be estimated accurately, however, because of variability in the chemical analysis of brines collected from any one well, as well as differences in the chemical composition of brines from neighboring wells. Further, the most valuable elements in the brines could well be the precious metals-gold, platinum, and silver, but those are present in trace amounts and the uncertainty in the chemical analysis of the brines, together with the variability in reported brine compositions, does not allow for good estimates. However, it is significant that both silver and gold have been reported as minor components of the scales obtained from Salton Sea high-temperature brines. ${ }^{5-8}$

\section{Chemical Composition of Salton Sea Geothermal Brines}

A number of studies have been made of the chemical composition of Salton Sea brines. For the purposes of this report, analyses of brines from the Magmamax No. 1 and Sinclair No. 4 
wells will be considered representative and will be used to estimate the potential for minerals production for a combined geothermal powerminerals recovery plant. The choice of these two wells is arbitrary, but the properties of their brines have been studied in some detail ${ }^{5,9,10}$ Although other wells in the area show equal or greater mineral contents, there are substantial differences in the trace-element composition from relatively closely spaced wells. The locations of these and other wells in the Salton Sea KGRA are shown in Figs. 1 and 2 (see Ref. 2).

The total dissolved solids, chloride concentration, and density of brine change with well flow rate. The reasons for these changes are not well understood, but are likely the result of transient effects during unsteady state operation and, perhaps, of larger inflows of deeper, moreconcentrated brines as flow rates increase. The large variability in chemical analyses reported for the Magmamax No. 1 well is shown in Table 1 for some Lawrence Livermore National Laboratory $(L L N L)^{5,10}$ data; the range of values in the compilation of Cosner and Apps $^{9}$ is even larger.

The chemical composition of the brines is so complex that systematic analytical errors can easily obtain. Thus the barium concentrations given in Table 1 were shown to be in error because of

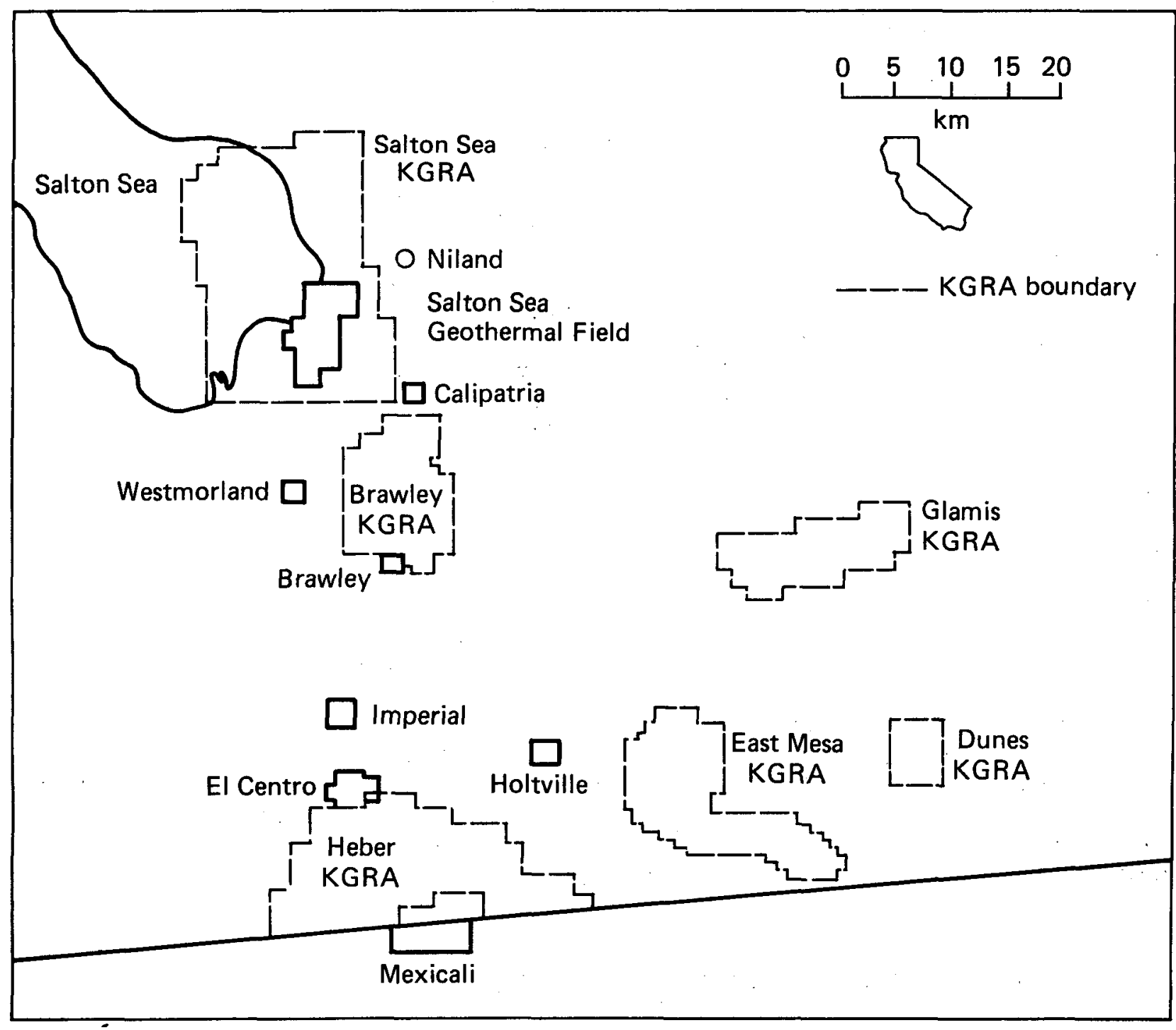

Figure 1. Map of the Imperial Valley, showing Known Geothermal Resource Areas (KGRA) and the Salton Sea Geothermal Field. 


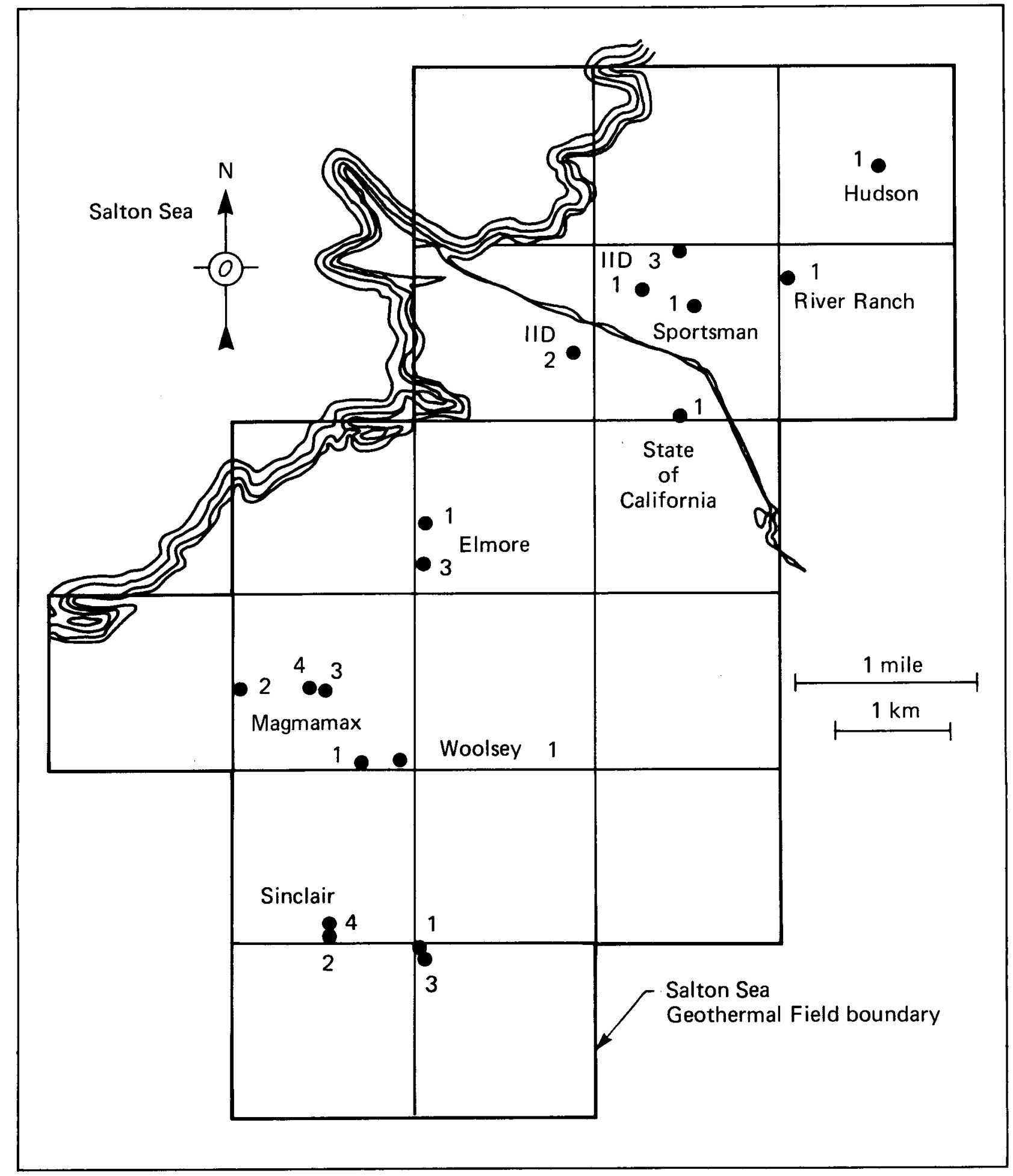

Figure 2. Well locations in the Salton Sea Geothermal Field. 
Table 1. Changes in brine composition during production of Magmamax No. 1.

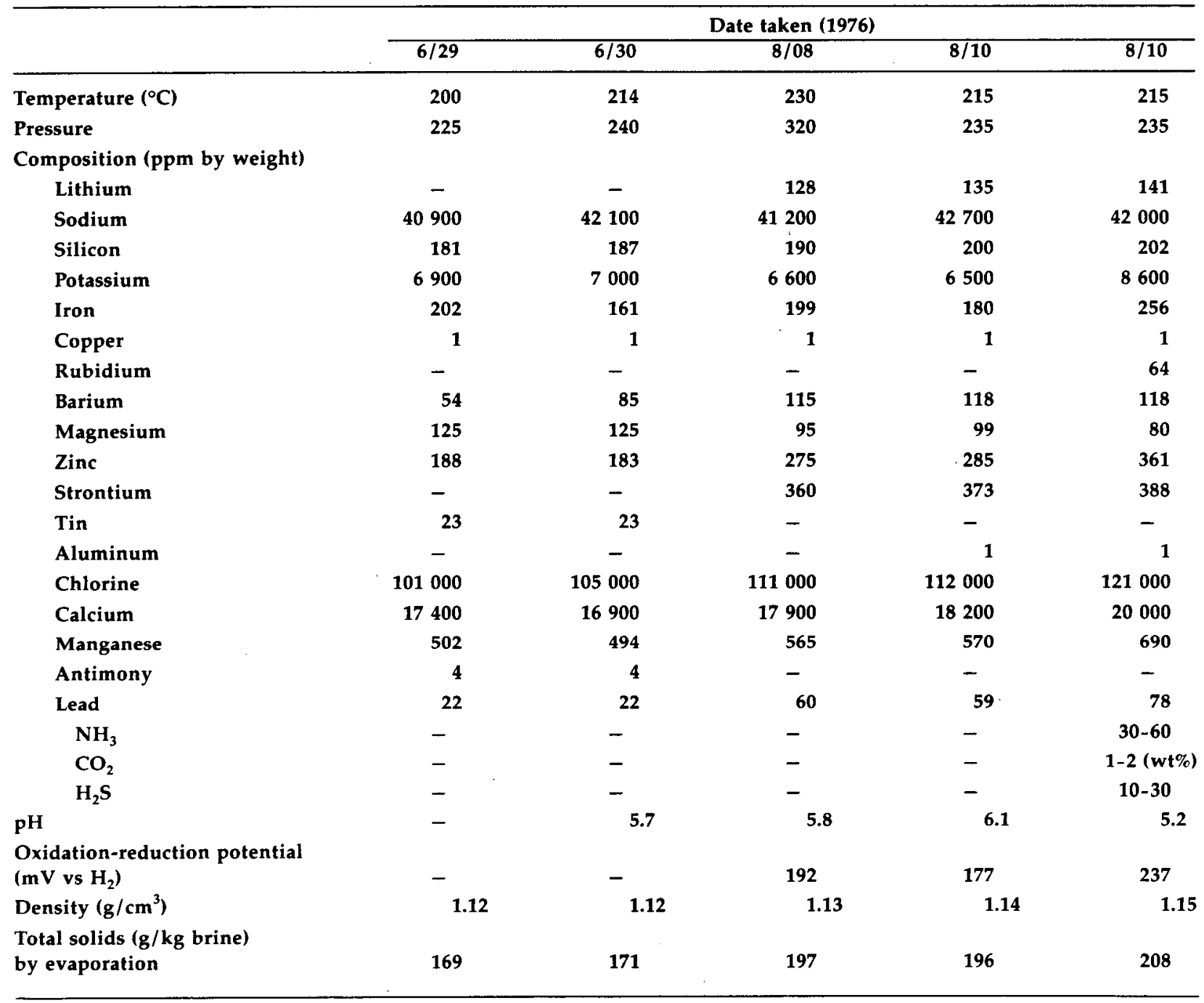

the precipitation of barium sulfate before sample analysis. A special sample was obtained and handled to minimize barium sulfate precipitation, and a barium content of $290 \mathrm{ppm}$ was measured $^{5}$ vs the 80-125 ppm reported in Table 1.

The situation for the precious metals-silver, gold, and platinum-is even more difficult because they are present only in trace concentrations. ${ }^{11}$ LLNL commissioned a special analysis at Ledoux Laboratories, Teaneck, New Jersey, which specializes in precious metals assays. Ledoux, using the fire-assay method of analysis, reported 0.5-0.7 ppm silver, $0.1 \mathrm{ppm}$ gold, and $0.06 \mathrm{ppm}$ platinum. The fire-assay method, a molten-salt extraction process performed on a sample of about $200 \mathrm{~g}$ of salts obtained by evaporating the brine, is very selective and is considered a standard for ore analysis. The silver analysis agrees with the values reported by Cosner and Apps. ${ }^{9}$ However, a recent study at SRI International ${ }^{12}$ indicates that silver analyses obtained by atomic absorption spectroscopy can be biased by matrix interferences. Using an extraction technique followed by flame atomic absorption, SRI researchers found $0.02 \mathrm{ppm}$ silver in Niland brines (San Diego Gas and Electric Geothermal Loop Experiment Facility, GLEF) stored at room temperature in plastic containers. This value should be compared to the $0.48 \mathrm{ppm}$ they had obtained in the initial analysis. However, none of the above analyses reflects the 
Table 2. "Typical" analysis for Magmamax No. 1 and Sinclair No. 4 brines.

\begin{tabular}{|c|c|c|}
\hline & Magmamax 1 & Sinclair 4 \\
\hline Total solids $(g / 1)$ & 190 & 294 \\
\hline pH & 5.6 & 5.2 \\
\hline Eh (vs NHE) & 0.18 & 0.18 \\
\hline \multicolumn{3}{|c|}{ Composition (ppm by weight) } \\
\hline $\mathrm{SiO}_{2}$ & 200 & 506 \\
\hline $\mathrm{NH}_{3}$ & 45 & 440 \\
\hline $\mathrm{Li}$ & 117 & 245 \\
\hline $\mathbf{K}$ & 8500 & 14300 \\
\hline $\mathbf{R b}$ & 56 & 25 \\
\hline $\mathbf{M g}$ & 75 & 68 \\
\hline Sr & 366 & 600 \\
\hline $\mathbf{B a}$ & 290 & - \\
\hline $\mathbf{M n}$ & 565 & 1260 \\
\hline Fe & 422 & 1300 \\
\hline Co & 0.3 & - \\
\hline Mo & 4 & - \\
\hline $\mathrm{Cu}$ & 0.8 & 3 \\
\hline $\mathrm{Zn}$ & 226 & 500 \\
\hline B & 10 & 300 \\
\hline Sn & 23 & - \\
\hline $\mathbf{P b}$ & 70 & 90 \\
\hline As & 0.2 & 7 \\
\hline Sb & 4 & - \\
\hline $\mathbf{B i}$ & 5 & - \\
\hline Se & 6 & 2.5 \\
\hline $\mathbf{A g}$ & 0.5 & 0.5 \\
\hline $\mathbf{A u}$ & 0.1 & 0.1 \\
\hline $\mathrm{Pt}$ & 0.06 & 0.06 \\
\hline
\end{tabular}

composition of the wellhead brines; the systematic variation in scale compositions described below indicates that some metals, particularly silver and lead, are more concentrated in the wellhead brine than in the aged, post-flash brines.

The total salt concentration of the brine is reflected very accurately by its density, and there is an almost perfect correlation between density and chloride concentration. Chloride concentrations tend to reflect the variation in relative concentration of most minor brine constituents. The solubility of silica is lower in the moreconcentrated brines. ${ }^{6}$

For the purposes of this study, and somewhat arbitrarily, "typical" post-flash brine compositions for room-temperature, aged brines from the Magmamax No. 1 and Sinclair No. 4 wells were developed by averaging the available chemical analyses and, in some cases, selecting "best" values. These "typical" analyses are shown in Table 2. The Ledoux values for silver, gold, and platinum are also included.

\section{Chemical Composition of Scales}

The substantial amount of scale deposited by Salton Sea brines during equipment operation has been a major impediment to the development of geothermal energy in the area. Brine from the Magmamax No. 1 well gave rise to scaling rates as high as $1 \mathrm{mil} / \mathrm{h}$ in the San Diego Gas and Electric Geothermal Loop Experiment Facility. The composition of some of those scales is discussed below. The chemical compositions of scales from other wells in the area have also been reported; 
Table 3. Analyses ${ }^{5}$ of scale from Magmamax No. 1 wellhead and the LLNL four-stage flash system after about $720 \mathrm{~h}$ of operation.

\begin{tabular}{|c|c|c|c|c|c|c|c|c|}
\hline \multirow[b]{2}{*}{ Element } & \multicolumn{8}{|c|}{ Composition, wt\% } \\
\hline & $\begin{array}{c}\text { Wellhead, } \\
220^{\circ} \mathrm{C}\end{array}$ & $\begin{array}{c}\text { Separated } \\
\text { unmodified brine, } \\
200-220^{\circ} \mathrm{C}\end{array}$ & $\begin{array}{c}\text { 2nd-stage } \\
\text { brine, } \\
150^{\circ} \mathrm{C} \\
\end{array}$ & $\begin{array}{c}\text { 2nd-stage } \\
\text { steam, } \\
150^{\circ} \mathrm{C} \\
\end{array}$ & $\begin{array}{c}\text { 3rd-stage } \\
\text { brine, } \\
125^{\circ} \mathrm{C} \\
\end{array}$ & $\begin{array}{c}\text { 3rd-stage } \\
\text { steam, } \\
125^{\circ} \mathrm{C} \\
\end{array}$ & $\begin{array}{c}\text { 4th-stage } \\
\text { brine, } \\
110^{\circ} \mathrm{C} \\
\end{array}$ & $\begin{array}{l}\text { Delay } \\
\text { line, } \\
85^{\circ} \mathrm{C} \\
\end{array}$ \\
\hline $\mathrm{Si}$ as $\mathrm{SiO}_{2}$ & 2 & 27 & 60 & 27 & 64 & 64 & 49 & 39 \\
\hline Li & $\mathbf{a}$ & 0.1 & $\mathbf{0 . 0 3}$ & 0.1 & 0.03 & 0.01 & 0.01 & 0.1 \\
\hline $\mathbf{N a}$ & $\mathbf{a}$ & 10 & 3 & 1 & 3 & 3 & $\mathbf{1}$ & 20 \\
\hline $\mathbf{K}$ & $<0.5$ & 1.6 & 1.3 & 1.5 & 0.64 & 0.82 & 0.8 & 1.4 \\
\hline $\mathbf{R b}$ & $<0.1$ & 0.01 & 0.02 & 0.02 & 0.007 & 0.004 & 0.003 & 0.01 \\
\hline Be & $\mathbf{a}$ & 0.0003 & 0.001 & 0.0006 & 0.0003 & 0.0003 & 0.002 & 0.0001 \\
\hline $\mathbf{M g}$ & $\mathbf{a}$ & 0.2 & 0.02 & 0.02 & 0.02 & 0.05 & 0.03 & 0.02 \\
\hline $\mathrm{Ca}$ & 2 & 4.2 & 2.0 & 1.2 & 2.7 & 2.9 & 26 & 6.1 \\
\hline $\mathrm{Sr}$ & trace & 0.06 & 0.04 & 0.01 & 0.22 & 0.03 & 0.12 & 0.40 \\
\hline $\mathbf{B}$ & $\mathbf{a}$ & 0.03 & 0.03 & 0.2 & 0.03 & 0.05 & 0.1 & 0.05 \\
\hline Al & $\mathbf{a}$ & 0.1 & 0.3 & 2 & 0.1 & 0.2 & 0.2 & 0.02 \\
\hline $\mathbf{Y}$ & $<1$ & $<0.005$ & 0.01 & 0.1 & $<0.005$ & $<0.005$ & 0.02 & $<0.005$ \\
\hline $\mathbf{S}$ & 12 & 2.4 & $<1.0$ & $<1.0$ & $<1.0$ & $<1.0$ & 1.5 & 2.3 \\
\hline As & $\mathbf{a}$ & 0.15 & 0.32 & 0.97 & 0.21 & 0.45 & 0.07 & 0.11 \\
\hline Sb & trace & 0.019 & 0.22 & 0.65 & 0.11 & 0.27 & 0.069 & 0.083 \\
\hline $\mathbf{T i}$ & 0.03 & $<0.05$ & $<0.05$ & $<0.05$ & $<0.5$ & $<0.05$ & $<0.2$ & $<0.8$ \\
\hline $\mathrm{Cr}$ & 0.09 & $<0.02$ & 0.03 & 0.34 & $<0.2$ & $<0.01$ & $<0.05$ & $<0.3$ \\
\hline Mn & 0.03 & 0.67 & 0.21 & 0.27 & 0.12 & 0.12 & 0.03 & 0.12 \\
\hline $\mathbf{F e}$ & 0.7 & 22 & 7.1 & 14 & 2.4 & 6.0 & 1.4 & 0.59 \\
\hline $\mathbf{N i}$ & 0.01 & $<0.01$ & 0.19 & 1.7 & 0.07 & 0.16 & 0.05 & $<0.01$ \\
\hline Mo & $\mathbf{a}$ & $<0.002$ & $<0.002$ & 0.004 & $<0.002$ & $<0.002$ & $<0.002$ & $<0.002$ \\
\hline $\mathrm{Zn}$ & 0.07 & 0.11 & 0.04 & 0.03 & 0.06 & 0.09 & 0.02 & 0.08 \\
\hline $\mathbf{P b}$ & 76 & 1.3 & 0.16 & 0.08 & 0.55 & 0.90 & 0.21 & 0.25 \\
\hline $\mathrm{CI}^{-}$ & $\mathbf{a}$ & 7.9 & 9.9 & 1.7 & 7.7 & 4.3 & 3.2 & 18 \\
\hline $\mathrm{Br}^{-}$ & $\mathbf{a}$ & 0.02 & $<0.01$ & $<0.01$ & $<0.01$ & $<0.01$ & $<0.01$ & $<0.01$ \\
\hline $\mathbf{F}^{-}$ & $\mathbf{a}$ & $\mathbf{a}$ & $\mathbf{a}$ & $\mathbf{a}$ & $\mathbf{a}$ & $\mathbf{a}$ & 26 & $\mathbf{a}$ \\
\hline
\end{tabular}

'Not determined.

for example, Skinner ${ }^{b}$ reports that six to eight tons of scale were collected during a three-month test of the No. 1 Imperial Irrigation District (IID No. 1) well. This scale contained "approximately $20 \%$ copper and precious metal values of several hundred ounces of silver plus one tenth of an ounce of gold per ton."

The LLNL Geothermal Program was carried out at the Magmamax No. 1 well, adjacent to the GLEF. A substantial part of the program was devoted to developing an understanding of brine chemistry and to methods for preventing scale deposition, as well as to brine treatment before reinjection. $5,7,10,13-18$

Suspended solids (about $7 \mathrm{ppm}^{10}$ ) collected at the wellhead of Magmamax No. 1 well were found to be almost pure lead sulfide. ${ }^{13}$ Substantial changes in scale composition were found as the brine flowed from the wellhead through the different stages of the LLNL four-stage system.

The scale compositions reported by Harrar et al. ${ }^{5}$ are given in Table 3 . Various compounds tend to precipitate preferentially at different points in the equipment, depending on respective temperatures, the concentration of such reactive volatile species as $\mathrm{H}_{2} \mathrm{~S}$ and $\mathrm{CO}_{2}$, and residence times.

Thus copper content was highest in the $200-220^{\circ} \mathrm{C}$ scales from the first-stage separator, and scale from the fourth-stage separator contained $26 \%$ fluorine as apatite $\left(\mathrm{CaF}_{2}\right)$. While the high-temperature wellhead scale contained only 
$4 \% \mathrm{SiO}_{2}$, lower-temperature scales contained up to $64 \%$ silica. Analysis of the scales obtained by LLNL during the nozzle expansion tests indicated that the primary metal sulfides were $\mathrm{PbS}, \mathrm{CuFeS}_{2}$, $\mathrm{ZnS}$, and $\mathrm{Cu}_{2} \mathrm{~S}$; the silver content increased downstream of the throat region and reached a maximum value of $1 \mathrm{wt} \%$ adjacent to the nozzle exhaust. ${ }^{10}$ The wellhead $\left(220^{\circ} \mathrm{C}\right)$ scale contained approximately $88 \%$ lead sulfide and $0.34 \%$ silver; however, the silver content of the lowertemperature scales in Table 3 is almost negligible. Similar results were reported by Carter and McCawley. ${ }^{19}$ In the case of silver, the higher concentration in the wellhead scales is probably due to the initial cooling in the presence of $\mathrm{H}_{2} \mathrm{~S}$; how-

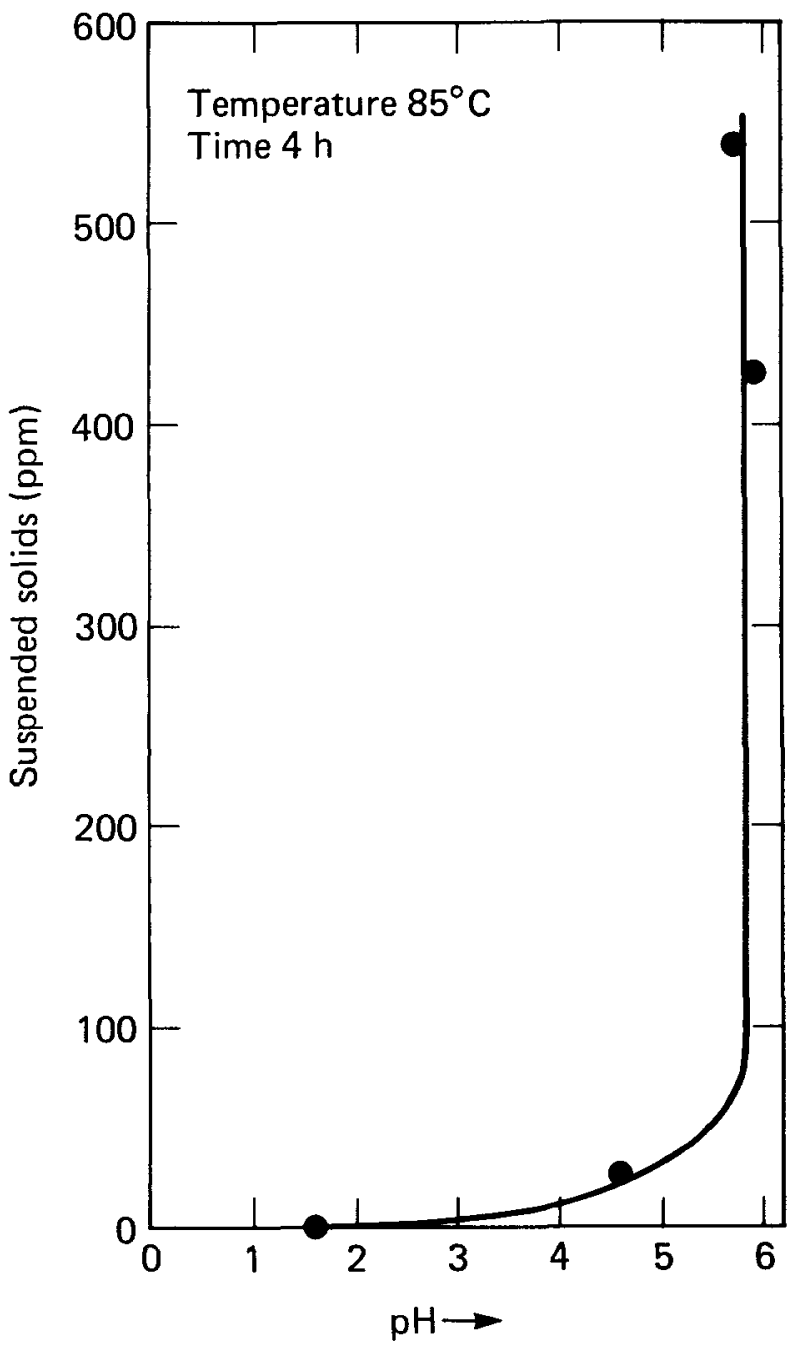

Figure 3. Suspended solids production in separated Magmamax No. 1 brine, as a function of pH. ever, metallic silver has also been reported. The high silver content of the wellhead scales implies that, unless precipitation is prevented, a process aimed at recovering the silver should interact with wellhead brines and scales.

Reduction of the rate of scale deposition in process equipment was an important part of LLNL's program. ${ }^{10,15,16}$ Large reductions in the rate of suspended solids production were obtained by acidification with $\mathrm{HCl}$, as well as by the addition of a variety of organic compounds. The reduction in the rate of scale deposition by additions of $\mathrm{HCl}$ is shown in Fig. 3 for $85^{\circ} \mathrm{C}$ brines, and the amounts of acid required are shown in Fig. 4. However, the reported increases in the corrosion rates on carbon steels were of concern; corrosion of mild steels will be discussed later in this report.

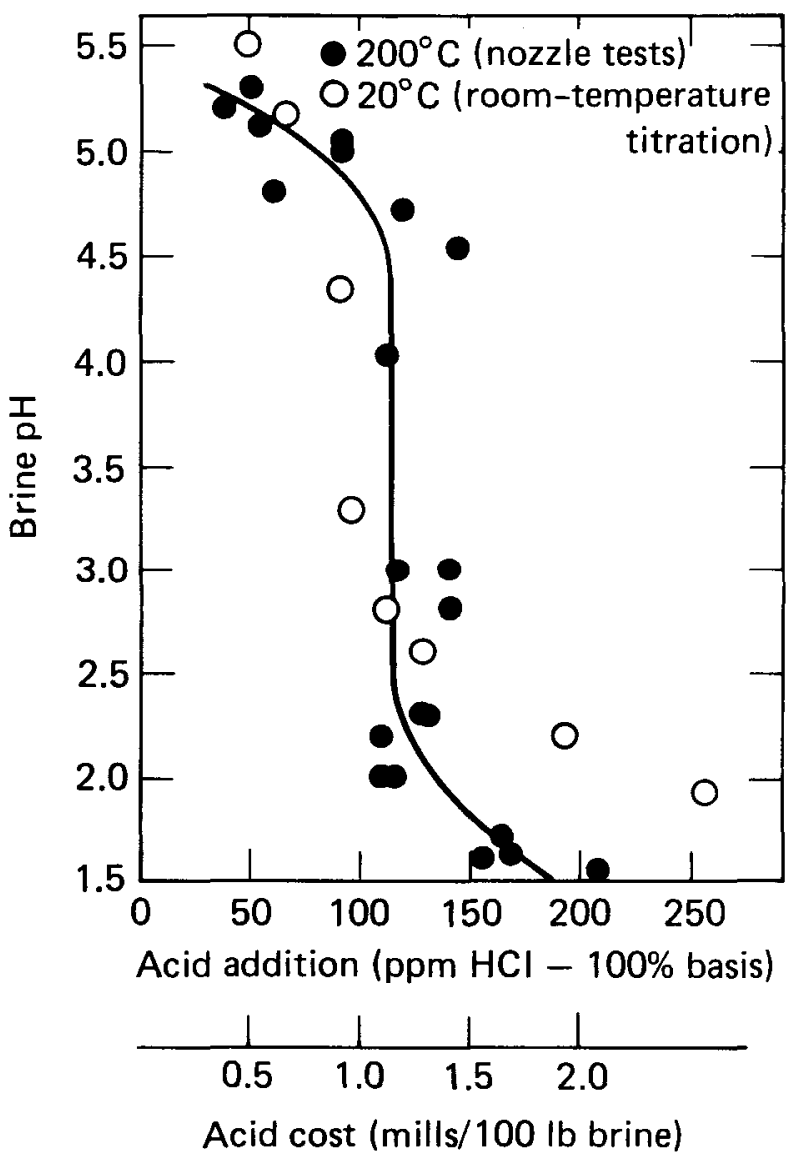

Figure 4. Acid-consumption measurements for $\mathrm{pH}$ control (separated Magmamax No. 1 brine). 


\section{Potential for Minerals Recovery from Salton Sea Geothermal Brines}

The possibility of minerals recovery from geothermal brines has been widely acknowledged; however, there are few detailed published studies on the subject. Werner, ${ }^{20}$ Barnea, ${ }^{21}$ and Blake $^{22}$ surveyed the minerals potential of geothermal brines and allude to some problems in the development of this resource. The U.S. Bureau of Mines has sponsored the only detailed published studies. Berthold et al. of Hazen Research ${ }^{23}$ performed a more-detailed study in which a large number of possible processes were illustrated by application to the most common elements present in the brines. The Hazen Research study culminated in the building and operation of a 15-gpm pilot plant at the Salton Sea. ${ }^{24,25}$ SRI International explored the possibilities of recovering heavy metals from Salton Sea brines by sulfide precipitation. ${ }^{12}$ The results obtained at Hazen Research and SRI International will be reviewed in more detail later.

The market value of possible products from a 1000-MWe combined geothermal power-minerals recovery plant is larger than the market value of the electric power production. A detailed listing is shown in Table 4.

Table 4 was developed using relatively conservative assumptions:

- The plant would have a $25 \%$ downtime, i.e., 6570 operating hours per year.

- Ninety percent of the mineral values in the brine would be recovered.

- Brine reinjection would be considered a basic necessity for long-term operations, with the minerals recovery processes limited to those achievable without evaporation of the brine.

Table 4. Potential minerals recovery from a 1000-MWe geothermal power-minerals recovery plant in the Salton Sea.

\begin{tabular}{|c|c|c|c|c|c|c|}
\hline \multirow[b]{2}{*}{ Element } & \multicolumn{2}{|c|}{$\begin{array}{l}\text { Potential minerals recovery } \\
\text { (thousand metric tons } / \mathrm{yr} \text { ) }\end{array}$} & \multirow{2}{*}{$\begin{array}{c}\text { U.S. consumption } \\
1980 \text { estimates } \\
\text { (thousand metric } \\
\text { tons }{ }^{3} \text { ) }\end{array}$} & \multirow{2}{*}{$\begin{array}{c}\text { Possible plant } \\
\text { product and market } \\
\text { value } 26,27 \\
(10 / 30 / 81)\end{array}$} & \multicolumn{2}{|c|}{$\begin{array}{l}\text { Market value of possible } \\
\text { plant product } \\
(\$ m i l l i o n / y r)\end{array}$} \\
\hline & Magmamax 1 & Sinclair 4 & & & Magmamax 1 & $\overline{\text { Sinclair } 4}$ \\
\hline $\mathrm{SiO}_{2}$ & 53 & 135 & - & $\begin{array}{l}\text { Amorphous drying } \\
\text { grade } 93 \%, \$ 31 / \text { ton }\end{array}$ & 1.8 & 4.6 \\
\hline $\mathrm{NH}_{3}$ & 12 & 117 & 15800 & $\begin{array}{l}\text { Aqueous } 29.4 \% \\
\text { anhydrous basis, } \\
\$ 210 / \text { ton }\end{array}$ & 2.7 & 27.1 \\
\hline $\mathbf{L i}$ & 31 & 65 & $4.7^{4}$ & $\mathrm{Li}_{2} \mathrm{CO}_{3}, \$ 1.41 / \mathrm{lb}$ & $(511)^{a}$ & $(1075)^{a}$ \\
\hline Mn & 150 & 335 & 1061 & $\begin{array}{l}\text { Ferromanganese } 78 \% \text {, } \\
0.1 \% \mathrm{C}, \$ 0.685 / \mathrm{lb}\end{array}$ & 290 & 648 \\
\hline $\mathbf{F e}$ & $112(79)^{b}$ & $346(272)^{b}$ & 69400 & $\begin{array}{l}\text { Black, magnetic iron } \\
\text { oxide, } \$ 0.25 / 1 \mathrm{~b}\end{array}$ & 28 & 97 \\
\hline $\mathrm{Cu}$ & 0.2 & 0.8 & 3902 & Metal, \$0.745/lb & - & - \\
\hline $\mathrm{Zn}$ & 60 & 133 & 920 & Metal, \$0.462/1b & 61 & 135 \\
\hline Sn & 6 & - & 53 & Metal, $\$ 6.86 / \mathrm{lb}$ & 90 & - \\
\hline $\mathbf{P b}$ & 18.6 & 24 & 1100 & Metal, $\$ 0.36 / 1 b$ & 14.8 & 19 \\
\hline Se & 1.6 & 0.7 & 0.4 & Metal, $\$ 3.80 / 1 b$ & 13.4 & 6 \\
\hline Subtotal & & & & & 502 & 938 \\
\hline $\mathbf{A g}^{\mathrm{c}}$ & 4.2 & 4.2 & 99 & Metal, $\$ 9.08 /$ troy oz & 38 & 38 \\
\hline $\mathbf{A} \mathbf{u}^{\mathrm{c}}$ & 0.8 & 0.8 & 3.0 & Metal, $\$ 426 /$ troy oz & 341 & 341 \\
\hline $\mathbf{P t}^{\mathbf{c}}$ & 0.5 & 0.5 & $2.2^{d}$ & Metal, $\$ 412 /$ troy oz & 206 & 206 \\
\hline Total & & & & & 1087 & 1523 \\
\hline
\end{tabular}

${ }^{2}$ Elasticity of lithium market not known.

${ }^{b}$ Iron in excess of that needed for $\mathbf{7 8 \%}$ ferromanganese production.

'Precious metals production in million troy ounces (31.104 $\mathrm{g}$ ).

${ }^{\mathrm{d}}$ Total consumption, platinum-group metals. 
- A net specific energy output (power plant efficiency) of 22 watt hours per kilogram of brine was assumed, corresponding to a brine flow rate of 45 million kilograms per hour. This value of specific energy is appropriate for current doubleflash systems, but lower than might be obtained from advanced geothermal power systems. ${ }^{28}$

If electric power sells for six cents per kilowatt hour, the market value of the power is $\$ 394$ million per year. The market value of the product slate shown in Table 4 ranges from about $\$ 500$ to
$\$ 1500$ million per year, depending on the assumptions made about the precious metals content of the brine. The above estimates do not include the value of the lithium chemicals since the potential production is so much larger than the current market. ${ }^{4}$

It is worthwhile noting that manganese production from such a plant could supply $14-31 \%$ of the U.S. demand for this strategic material. ${ }^{3}$ Substantial amounts of zinc, lead, tin, and selenium could also be recovered.

\section{Review of Prior Work}

\section{Hazen Research Incorporated}

Hazen Research, Incorporated, Golden, Colorado, conducted laboratory ${ }^{24}$ and pilot plant tests $^{25}$ in the Salton Sea. While the pilot plant was operated successfully, the results are still being analyzed and a final report is not available.

Their laboratory studies using Sinclair No. 4 brines indicated that iron could be separated from manganese, zinc, and lead by selective precipitation of the respective hydrated oxides. Processes for the separation of lithium, barium, and strontium without evaporation of the brine were also explored.

Hazen's process is based on selective precipitation of the hydroxides using lime. They found better separation when the iron was oxidized to the ferric state by sparging air through the brine. Ninety-nine percent of the lithium was recovered as aluminate, and partial recovery of barium was obtained by the addition of gypsum. Recovery of strontium requires evaporation of the brine. In laboratory experiments, Hazen was able to obtain a hydrated magnetic iron oxide containing more than $68 \%$ iron and less than $0.1 \%$ manganese. The manganese precipitate contained $47.3 \%$ manganese, $18.2 \%$ zinc, and $2.6 \%$ lead with $0.6 \%$ iron contamination. Their experiments also indicated that it would be advantageous to remove the silica present in the brine before precipitating the heavy metal hydroxides.

Hazen then designed and operated a 15-gpm pilot plant, using post-flash brine from the GLEF plant of San Diego Gas and Electric at the Magmamax No. 1 well. While their complete design flow sheet with nominal flows and compositions ${ }^{25}$ is given in Fig. 5 and Table 5, the actual pilot plant used just one lime-precipitation step in which a comingled precipitate containing iron, manganese, and zinc was obtained. As mentioned earlier, the results of the pilot plant experiments are not yet available; however, information obtained informally from Mr. L. Schultze of the Reno Metallurgy Research Center, U.S. Bureau of Mines $^{26}$ indicated that:

- The Pilot Plant was operated in the spring of 1980, following the original Hazen flow sheet, with minor modifications.

- The silica-separation step was not very effective, and silica was found to contaminate the products.

- The single (bulk) lime-precipitation step allowed them to recover about $90 \%$ of the metals of interest, but had difficulty in separating the iron, lead, and zinc into materials pure enough to be of commercial interest. However, the precipitates had aged for about one year before further separation was attempted.

- They used aqueous ammonia and ammonium chloride solutions to separate zinc from the aged, mixed precipitate indicated above; however, they were only able to recover about $50 \%$ of the zinc present.

- They obtained good separation of lithium and are investigating means of recycling the aluminum.

- A large number of samples remain to be analyzed.

\section{SRI International}

The process investigated at SRI International, ${ }^{12}$ Menlo Park, California, involved precipitation of the more-valuable elements in the brine by use of a sulfiding agent, such as $\mathrm{H}_{2} \mathrm{~S}, \mathrm{NaHS}$, or 
$\mathrm{Na}_{2} \mathrm{~S}$. SRI performed a number of equilibrium calculations, as well as laboratory experiments, using Magmamax and Woosley brines, including a 14-1/h flow experiment using aged, spent brine from the GLEF. Their "goal was to precipitate essentially all the silver, lead, and zinc, while minimizing the precipitation of iron and manganese and using as little of the sulfide as possible." Their equipment for continuous sulfidation is shown in Fig. 6.
Calculations indicated that the insolubilities of the metal sulfides are in the order $\mathrm{Ag}, \mathrm{Pb}, \mathrm{Zn}$, $\mathrm{Fe}$, and $\mathrm{Mn}$.

Experimentally, SRI found that lead and silver sulfides can be precipitated preferentially before zinc, iron, and manganese sulfides.

Their small-scale batch experiments, using $\mathrm{H}_{2} \mathrm{~S}$ at $100^{\circ} \mathrm{C}$ and a $\mathrm{pH}$ of about 3 , indicated that $\mathrm{H}_{2} \mathrm{~S}$ at about one atmosphere led to precipitation of about half of the zinc present. However, only

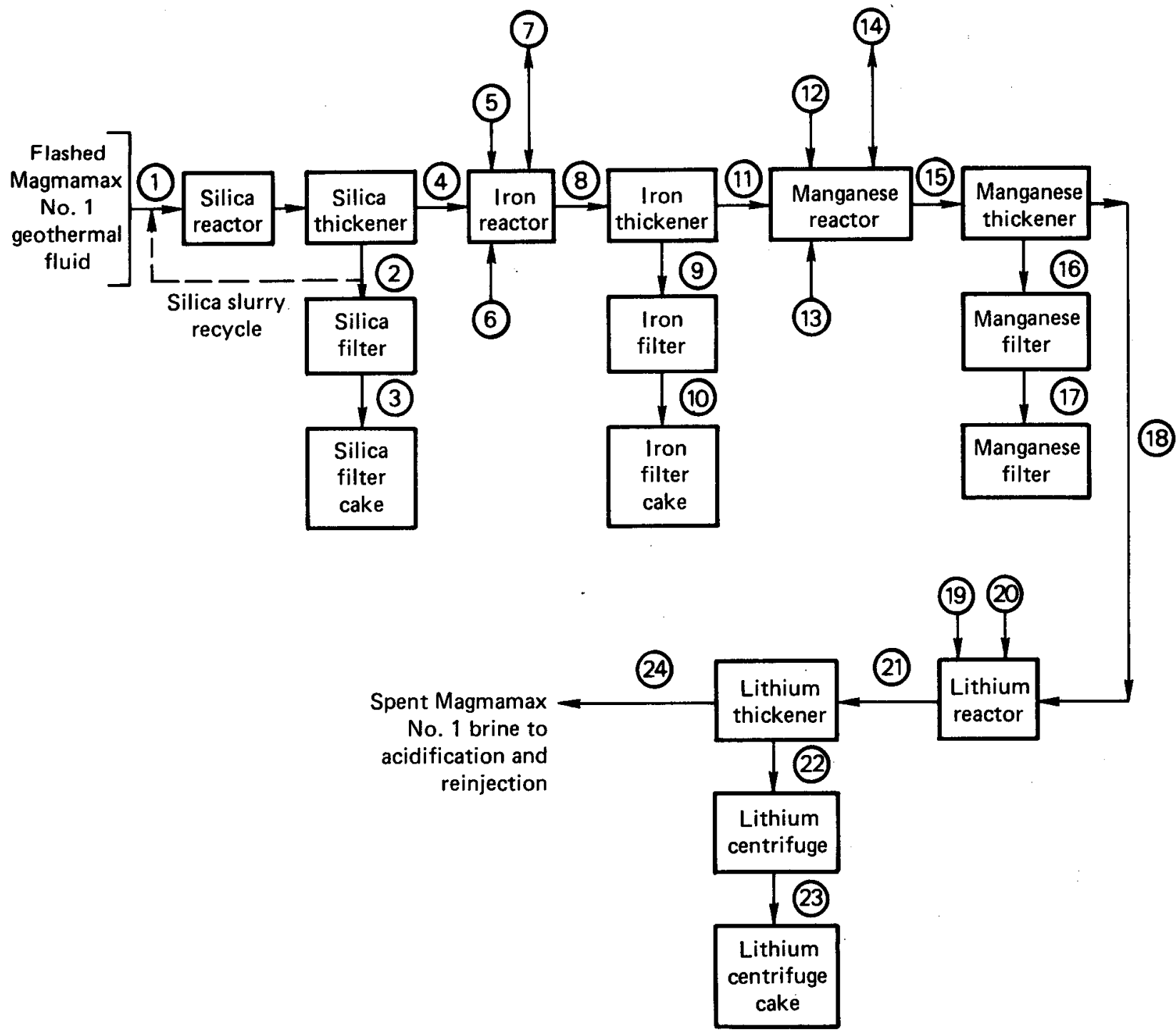

Figure 5. Process materials balance of Magmamax No. 1 brine (Hazen Research). 
Table 5. Process flow sheet for Magmamax No. 1 brine (Hazen Research, Inc.).

\begin{tabular}{|c|c|c|c|c|c|c|c|c|c|c|c|c|}
\hline & \multicolumn{12}{|c|}{ Stream No. } \\
\hline & 1 & 2 & 3 & 4 & 5 & 6 & 7 & 8 & 9 & 10 & 11 & 12 \\
\hline $\mathrm{SiO}_{2}$ & $\begin{array}{l}230 \mathrm{ppm} \text { total } \\
187 \mathrm{ppm} \text { solid }\end{array}$ & $\begin{array}{c}1.6 \mathrm{lb} / \mathrm{h} \\
10.2 \mathrm{wt} \%\end{array}$ & $\begin{array}{l}1.6 \mathrm{lb} / \mathrm{h} \\
60 \mathrm{wt} \%\end{array}$ & 43 ppm & & & & $43 \mathrm{ppm}$ & $\begin{array}{l}0.16 \mathrm{lb} / \mathrm{h} \\
\text { solids }\end{array}$ & & $22 \mathrm{ppm}$ & \\
\hline $\mathrm{Fe}$ & 255 ppm & & & $255 \mathrm{ppm}$ & & & & $\begin{array}{c}255 \mathrm{ppm} \\
\text { total }\end{array}$ & $\begin{array}{c}375 \mathrm{lb} / \mathrm{h} \\
\text { solids }\end{array}$ & & $26 \mathrm{ppm}$ & \\
\hline $\mathrm{Zn}$ & 333 ppm & & & 333 ppm & & & & 333 ppm & & & 333 ppm & \\
\hline $\mathrm{Mn}$ & 775 ppm & & & 775 ppm & & & & 775 ppm & & & 775 ppm & \\
\hline $\mathrm{Pb}$ & 70 ppm & & & 70 ppm & & & & $70 \mathrm{ppm}$ & $\begin{array}{l}0.13 \mathrm{lb} / \mathrm{h} \\
\text { solids }\end{array}$ & & $56 \mathrm{ppm}$ & \\
\hline $\mathrm{Li}$ & $182 \mathrm{ppm}$ & & & $182 \mathrm{ppm}$ & & & & $182 \mathrm{ppm}$ & & & 182 ppm & \\
\hline Inertia & $22.1 \%$ & & & $22.1 \%$ & & & & $22.1 \%$ & & & $22.1 \%$ & \\
\hline $\mathrm{H}_{2} \mathrm{O}$ & $77.7 \%$ & & & $77.7 \%$ & & & $7 \mathrm{lb} / \mathrm{h}$ & $77.7 \%$ & & & $77.1 \%$ & \\
\hline Specific grey & 1.135 & 1.20 & & 1.135 & 1.22 & & & 1.14 & 1.32 & 1.9 & 1.13 & 1.22 \\
\hline Temp. ${ }^{\circ} \mathrm{C}$ & 93 & 93 & 93 & 93 & 25 & 29 & 92 & 92 & 92 & 92 & 92 & 25 \\
\hline Temp. $^{\circ} \mathrm{F}$ & 200 & 200 & 200 & 200 & 77 & 85 & 198 & 198 & 198 & 198 & 198 & 77 \\
\hline Flow, gpm & 15 & 0.025 & & 15 & 0.025 & & & 15 & 0.03 & & 15 & 0.088 \\
\hline Flow, gph & 900 & 1.5 & & 900 & 1.50 & & & 901 & 1.8 & & 901 & 5.25 \\
\hline Flow, cfm & - & - & & & & 5.0 & 6.2 & & & & & \\
\hline Flow, lb/h & 8523 & 15.0 & 2.67 & 8520 & 15.3 & & & 8528 & 20 & 6.8 & 8508 & 54 \\
\hline $\begin{array}{l}\text { Specific heat } \\
\text { Btu/lb }{ }^{\circ} \mathrm{F}\end{array}$ & 0.85 & 0.78 & 0.46 & 0.85 & 0.77 & & & 0.85 & & 0.48 & 0.85 & 0.77 \\
\hline Heat Btu/h & $1.45 \times 10^{6}$ & 2340 & 2.46 & $1.45 \times 10^{6}$ & 2471 & & & $144 \times 10^{6}$ & & 646 & $144 \times 10^{6}$ & 10,656 \\
\hline Density & $9.47 \mathrm{lb} / \mathrm{gal}$ & $9.99 \mathrm{lb} / \mathrm{gal}$ & $\approx 50 \mathrm{lb} / \mathrm{ft}^{3}$ & $9.47 \mathrm{lb} / \mathrm{gal}$ & $10.2 \mathrm{lb} / \mathrm{gal}$ & & & $951 \mathrm{lb} / \mathrm{gal}$ & $11.0 \mathrm{lb} / \mathrm{gal}$ & $15.8 \mathrm{lb} / \mathrm{gal}$ & $944 \mathrm{lb} / \mathrm{gal}$ & $10.2 \mathrm{lb} / \mathrm{gal}$ \\
\hline $\mathrm{NH}_{3}$ & $352 \mathrm{ppm}$ & & & $352 \mathrm{ppm}$ & & & & $352 \mathrm{ppm}$ & & & $352 \mathrm{ppm}$ & \\
\hline
\end{tabular}


Table 5. (Continued.)

\begin{tabular}{|c|c|c|c|c|c|c|c|c|c|c|c|c|}
\hline & & & & & & & tream No. & & & & & \\
\hline & 13 & 14 & 15 & 16 & 17 & 18 & 19 & 20 & 21 & 22 & 23 & 24 \\
\hline $\mathrm{SiO}_{2}$ & & & & & & & & & & & & \\
\hline $\mathrm{Fe}$ & & & $26 \mathrm{ppm}$ & $0.21 \mathrm{lb} / \mathrm{h}$ & & $13 \mathrm{ppm}$ & & & $13 \mathrm{ppm}$ & & & 13 ppm \\
\hline $\mathrm{Zn}$ & & & $333 \mathrm{ppm}$ & $4.11 \mathrm{lb} / \mathrm{h}$ & & $17 \mathrm{ppm}$ & & & $17 \mathrm{ppm}$ & & & $17 \mathrm{ppm}$ \\
\hline $\mathrm{Mn}$ & & & 775 ppm & $10.06 \mathrm{lb} / \mathrm{h}$ & & $39 \mathrm{ppm}$ & & & $39 \mathrm{ppm}$ & & & $39 \mathrm{ppm}$ \\
\hline $\mathrm{Pb}$ & & & $56 \mathrm{ppm}$ & $0.48 \mathrm{lb} / \mathrm{h}$ & & $6 \mathrm{ppm}$ & & & $6 \mathrm{ppm}$ & & & $6 \mathrm{ppm}$ \\
\hline $\mathrm{Li}$ & & & $182 \mathrm{ppm}$ & & & $182 \mathrm{ppm}$ & & & $182 \mathrm{ppm}$ & $43 \mathrm{lb} / \mathrm{h}$ solids & & $18 \mathrm{ppm}$ \\
\hline Inertia & & & $22.1 \%$ & & & $22.1 \%$ & & & $22.1 \%$ & & & $22.1 \%$ \\
\hline $\mathrm{H}_{2} \mathrm{O}$ & & $20 \mathrm{lb} / \mathrm{h}$ & $777 \%$ & & & $77.8 \%$ & & & $77.0 \%$ & & & $77.0 \%$ \\
\hline Specific grey & & & 1.132 & 1.303 & 1.86 & 1.13 & 1.109 & 1.315 & 1.13 & 1.434 & 1.86 & 1.13 \\
\hline Temp. ${ }^{\circ} \mathrm{C}$ & 29 & 90 & 90 & 90 & 90 & 90 & 25 & 25 & 90 & 90 & 90 & 90 \\
\hline Temp. $^{\circ} \mathrm{F}$ & 85 & 195 & 195 & 195 & 195 & 195 & 77 & 77 & 195 & 195 & 195 & 195 \\
\hline Flow, gpm & & & 15 & 0.11 & & 15 & 0.22 & 0.05 & 15.3 & 0.15 & 0.1 & 15 \\
\hline Flow, gph & & & 904 & 6.8 & 1.6 & 902 & 13.6 & 2.8 & 918 & 9.2 & 5.8 & 912 \\
\hline Flow, cfm & 12.4 & 16.0 & & & & & & & & & & \\
\hline Flow, lb/h & & & 8540 & 74 & 24.8 & 8515 & 126 & 31 & 8672 & 110 & 78 & 8594 \\
\hline $\begin{array}{c}\text { Specific heat } \\
\text { Btu/lb }{ }^{\circ} \mathrm{F}\end{array}$ & & & 0.85 & & & 0.85 & 0.78 & 0.67 & 0.85 & & 0.48 & 0.85 \\
\hline Heat Btu/h & & & $1.41 \times 10^{6}$ & & 2176 & $1.41 \times 10^{6}$ & 7568 & 16,000 & $1.44 \times 10^{6}$ & & 7301 & $1.43 \times 10^{6}$ \\
\hline Density & & & $9.45 \mathrm{lb} / \mathrm{gal}$ & $10.9 \mathrm{lb} / \mathrm{gal}$ & $15.5 \mathrm{lb} / \mathrm{gal}$ & $9.44 \mathrm{lb} / \mathrm{gal}$ & $9.24 \mathrm{lb} / \mathrm{gal}$ & $10.9 \mathrm{lb} / \mathrm{gal}$ & $9.45 \mathrm{lb} / \mathrm{gal}$ & $12.0 \mathrm{lb} / \mathrm{gal}$ & $15.5 \mathrm{lb} / \mathrm{gal}$ & $9.43 \mathrm{lb} / \mathrm{gal}$ \\
\hline $\mathrm{NH}_{3}$ & & $3.0 \mathrm{lb} / \mathrm{h}$ & $352 \mathrm{ppm}$ & & & $35 \mathrm{ppm}$ & & & $35 \mathrm{ppm}$ & & & 35 ppm \\
\hline
\end{tabular}




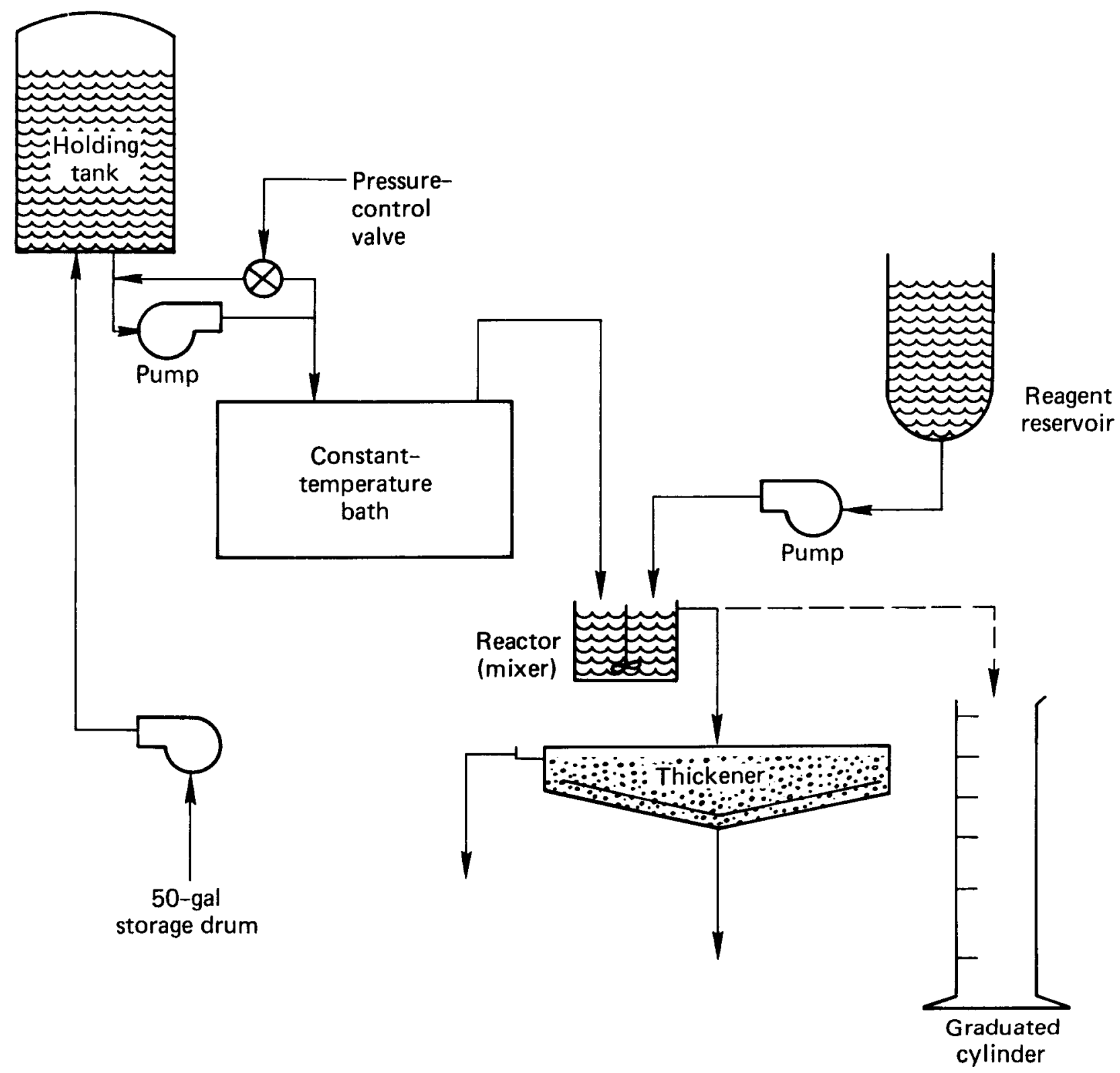

Figure 6. Continuous sulfidation apparatus (SRI International).

about half of the lead precipitated when the $\mathrm{H}_{2} \mathrm{~S}$ partial pressure was reduced to about $0.01 \mathrm{~atm}$. Precipitation with hydrogen sulfide is very fast and leads to plugging of the injection nozzle.

These small-scale batch experiments led SRI to use $\mathrm{Na}_{2} \mathrm{~S}$ in their flow experiments. Under conditions for $85 \% \mathrm{Zn}$ recovery, the composition of the precipitates was $31 \% \mathrm{ZnS}, 5 \% \mathrm{PbS}, 14 \% \mathrm{MnS}$, and $41 \%$ insolubles, most of which was silica. The amounts of precipitated iron and manganese can be reduced by operating at a lower $\mathrm{pH}$; however, this increases the amount of sulfide reagent required. Since substantial silica precipitation occurs during sulfidation, they concluded that silica had to be removed before sulfidation. Silica scale was particularly evident in their experiments with Niland brine.

SRI did a careful study of analytical techniques for silver in the brines and concluded that standard atomic absorption techniques tend to overestimate the concentration of silver in the brine. They developed a solvent extraction technique using dithizone (diphenylthio-carbazone)EDTA (ethylenediamine-tetracetic acid)-in chloroform and concluded that the silver content of the aged, spent brine was $0.02 \mathrm{ppm}$. The silver 
content of their sulfide precipitates was only 70 ppm, consistent with the silver content of the lower-temperature scales given in Table 3. This low silver content in the aged, room-temperature brines is to be expected.
They were able to remove about $70 \%$ of the lead in Niland brine by cementation on iron turnings, but did not realize the potential of cementation as a separation process.

\section{Proposed Cementation Process}

Ideally, one would like a process scheme in which successive steps are implemented only if economically desirable, in which materials with the highest value are recovered first, and which provides a reasonable purity for the different products. Smelters usually do not give credit for potential byproducts from an ore. The results obtained by Hazen Research indicate that it would be advantageous to remove the silver, copper, and lead prior to the precipitation of zinc, iron, and manganese, perhaps using a sulfide precipitation or electrolytic separation.

The SRI results indicated that a separation by sulfide precipitation can be used to recover the most valuable elements; however, it leads to a mixed sulfide product. Also, it is somewhat difficult to interact with the wellhead brines, and integration of the silica-removal step with the rest of the process has not been studied.

Hydrogen sulfide added at the wellhead would be flashed at the power plant, leading to possible redissolution of the precipitates; the hydrogen sulfide would become a part of the noncondensable exit gases. However, small-scale experiments demonstrated that the spent brines are effective in scrubbing $\mathrm{H}_{2} \mathrm{~S}$ from the noncondensable gases. ${ }^{29}$ Thus, this gas could be reacted with the brines leaving the power plant. Precipitation of the wellhead brine with sodium sulfide would lead to gross silica scaling and contamination.

The results of a cursory experiment by Schock and Duba ${ }^{7}$ indicate that electrolysis of unacidified brine is not likely to lead to a clean separation since the kinetics of scale precipitation seem to dominate the composition of products deposited in the electrodes, although silver concentrations as high as $2 \%$ were obtained in the cathodes. However, controlled potential electrolysis of acidified brine could be a viable process. ${ }^{30}$ Since many of the technical issues associated with electrolytic recovery are closely related to the metal cementation process to be outlined below, a research program in this area should include the development of information required for either approach.

Adsorption on activated carbon and selective ion-exchange resins of various kinds is also possible, particularly for the precious metals. However, the untreated brines will deposit scale on the adsorbent and destroy its selectivity. ${ }^{31}$ The economics of using a reducing adsorbent, such as Rohm and Haas AMBORANE resins with acidified brine, are likely to be less favorable than alternative processes.

The use of cementation is another alternative. Cementation is used to recover copper from solutions using metallic iron. It also has been applied to the reduction and precipitation of a variety of metals from solution, using metallic iron or zinc as the reducing agent. Electrolysis is another option. The general cementation reaction is:

$\mathrm{M}_{1}^{\mathrm{n}+}+\mathrm{M}_{2}^{\circ} \rightarrow \mathrm{M}_{1}^{\mathrm{o}}+\frac{\mathrm{n}}{2} \mathrm{M}_{2}^{2+}$.

Cementation of lead from unacidified Salton Sea brines was reported in the SRI study ${ }^{12}$; that from acidified brines was reported by Harrar et al. ${ }^{32}$ Exposure of a virgin steel surface to acidified brine at a pH of 2-3 results in nearly complete surface coverage by a deposit consisting of metallic lead, lead carbonate, a copper-rich phase, and lesser amounts of iron corrosion products.

\section{Cementation Equilibria}

Although there are many possible options, the cementation process will be described using metallic iron as the reducing agent. One can obtain approximate values for the equilibrium concentrations in contact with metallic iron. The results of such a calculation, using standard thermodynamic potentials at $25^{\circ} \mathrm{C}$ and unit activity coefficients, are shown in Table 6 . While one should expect essentially complete precipitation 
Table 6. Cementation equilibria. Metallic iron, $25^{\circ} \mathrm{C}$, unit activity coefficients.

\begin{tabular}{lcc}
\hline Ionic & \multicolumn{2}{c}{ Concentration } \\
\cline { 2 - 3 } species & g-mole/1 & Ppm \\
\hline $\mathrm{Ag}^{+}$ & $1.5 \times 10^{20}$ & $1.8 \times 10^{12}$ \\
$\mathrm{Cu}^{++}$ & $1.0 \times 10^{24}$ & $7.2 \times 10^{17}$ \\
$\mathrm{~Pb}^{++}$ & $4.5 \times 10^{9}$ & 1.0 \\
$\mathrm{Sn}^{++}$ & $1.0 \times 10^{8}$ & 1.4 \\
\hline
\end{tabular}

of silver and copper, the equilibrium concentrations for lead and tin are of the order of $1 \mathrm{ppm}$ by weight. Since the wellhead brines contain hydrogen sulfide (10-30 ppm by weight), some metals in solution will precipitate as sulfides, and the resulting cements are likely to be mixtures of metals and metal sulfides. Table 7 gives an estimate of the metals content of the resulting cements for the Magmamax No. 1 and Sinclair No. 4 wells. The economic value of the cement will depend critically on the precious metals content, but a base is provided by the lead and tin prices.

\section{Cementation Process Flow Sheet}

The recovery of metal values from the Salton Sea brines imposes special requirements on the cementation equipment:

- Since the flows are quite large $(171,000$ gpm for a $1000-M W e$ plant) and the solutions very dilute in heavy-metal ions, the process has to be able to handle large flows economically and efficiently.
- The equipment has to be designed to minimize plugging by scales or by the product cement.

- The brine has to be treated to prevent deposition of silica on the metallic iron (or electrodes) used for cementation, the product cement, and the power equipment. The likely optimum treatment is acidification to a $\mathrm{pH}$ of about 3 .

- The equipment has to be designed to minimize air oxidation of the brine, which would lead to increased iron consumption and premature precipitation of hydrated ferric hydroxides.

Of the various types of equipment used commercially for cementation, the fluidized-bed reactor is probably best suited for application to Salton Sea brines, particularly since it lends itself to large-scale operations. There is also considerable experience available regarding methods for the design of large units. Alternatives to the fluidizedbed reactor include ball mills of various types, such as vibratory mills, the Koppers Tower Mills, etc. Laboratory experiments have been reported on fluidized cathode cementation in a rotating drum. ${ }^{33}$

A preliminary flow sheet for a cementation process using metallic iron as the reducing agent is shown in Fig. 7. It also includes the main features of the Hazen process.

The wellhead brines are acidified and mixed with recycled fines containing metallic iron. The purpose of acidification is to prevent silica from precipitating onto the metallic iron and hindering the cementation process. While the acidified brine is expected to be somewhat more corrosive than untreated brine, acidification of brine was one of the techniques considered in detail by the LLNL geothermal energy program.

Table 7. Estimated cement compositon (\%).

\begin{tabular}{lcccc}
\hline & \multicolumn{2}{c}{ Magmamax 1 } & & Sinclair 4 \\
\cline { 2 - 5 } $\begin{array}{l}\text { Precious } \\
\text { metal }\end{array}$ & $\begin{array}{c}\text { Precious metal } \\
\text { included }\end{array}$ & $\begin{array}{c}\text { No precious } \\
\text { metal }\end{array}$ & $\begin{array}{c}\text { Precious metal } \\
\text { included }\end{array}$ & $\begin{array}{c}\text { No precious } \\
\text { metal }\end{array}$ \\
\hline Copper & 0.7 & 0.7 & 2.9 & 2.9 \\
Lead & 64.7 & 65 & 87.1 & - \\
Tin & 19.7 & 19.8 & - & 6.9 \\
Arsenic & 0.2 & 0.2 & - & - \\
Antimony & 3.7 & 3.8 & - & - \\
Bismuth & 4.7 & 4.7 & 2.4 & - \\
Selenium & 5.6 & 5.7 & 0.5 & - \\
Silver & 0.5 & - & 0.1 & - \\
Gold & 0.1 & - & 0.06 & - \\
Platinum & 0.06 & - & 99.9 & 100 \\
& 100 & 99.9 & & - \\
\hline
\end{tabular}

aiven the chemical analysis of Table 2 and the equilibria of Table 6. 


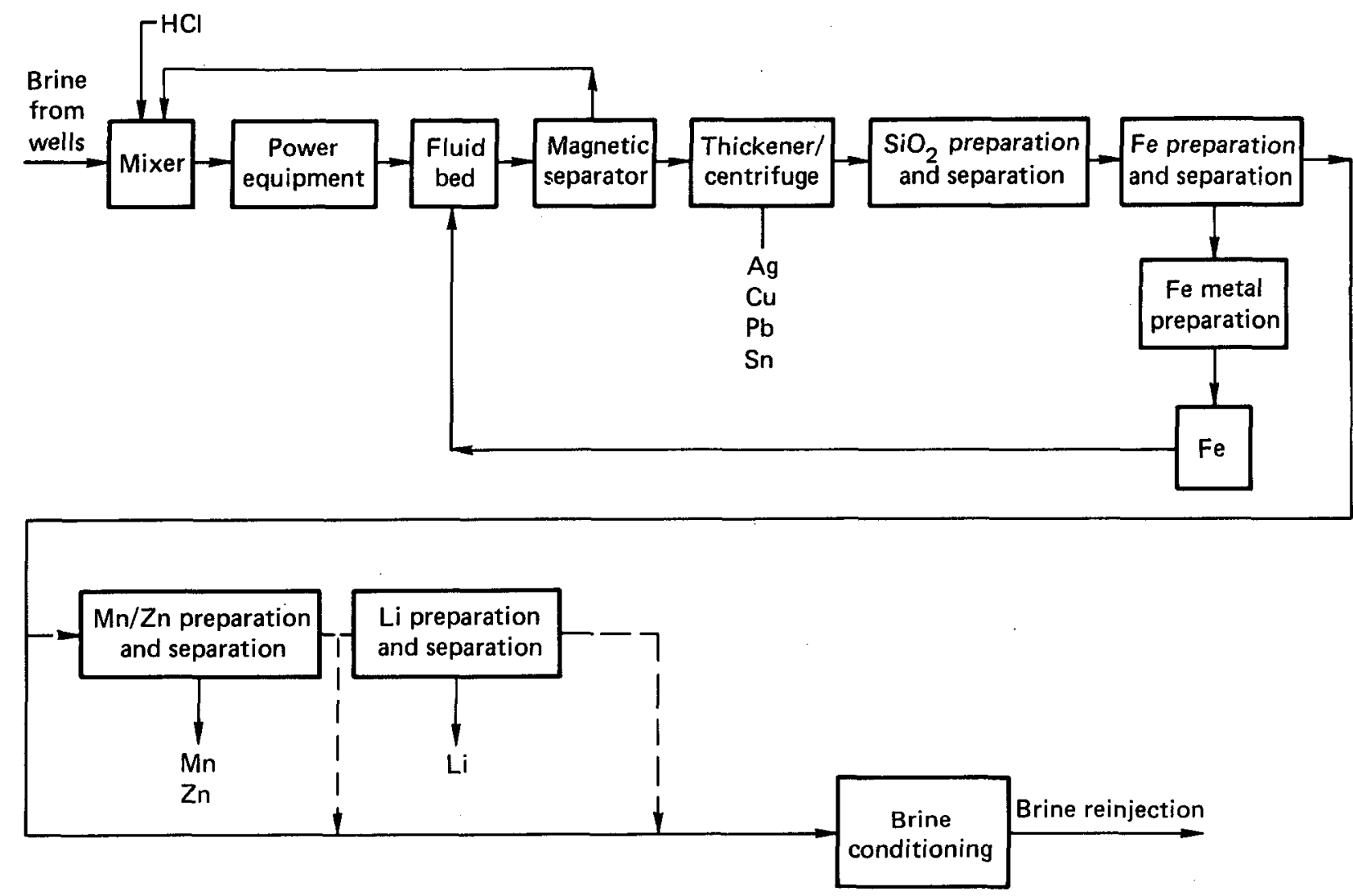

Figure 7. Steps in minerals recovery from Salton Sea brines.

As acidified brine flows through the power equipment, such as two-stage flash, the metallic iron in the fines acts as a nucleation center for the precipitation of supersaturated sulfides and as a reducing agent for the precipitation of metals. Brines leaving the power equipment then enter the fluidized bed(s). While fluidized beds have not been designed in detail, it is likely that the final configuration would involve a number of short, conical fluidized beds operating in series to achieve maximum recovery of precious metal values. Fines elutriated from the fluidized beds proceed to a magnetic separator, where iron containing fines is separated for recycling. The cement then proceeds to separating equipment, which could consist of a combination of thickeners with filters or centrifuges.

Implementation of the rest of the process flow sheet shown in Fig. 7 depends on the relative economics of conducting the different operations. The recovery and reduction of iron used in the cementation step, in particular, is likely to be economically advantageous. While brine treatment will be required before reinjection, the detailed process to be used will depend on subsequent minerals recovery steps.

One alternative to the Hazen process in the iron-separation step is to attempt precipitation of goethite $(\mathrm{FeO} \mathrm{OH})$ by air oxidation of the acidified brines before silica removal. It has been reported ${ }^{34}$ that goethite can be precipitated by air oxidation of chloride solutions containing iron at a $\mathrm{pH}$ of $\mathbf{2 . 6}$ and $80^{\circ} \mathrm{C}$; the precipitate is reported to be easily filterable. This process step might be carried out before the silica-precipitation step and would be particularly advantageous if recovery of manganese and zinc were not contemplated.

\section{Corrosion and Cementation Rates}

Corrosion of mild steels by Salton Sea brines can be explained by the presence of a small amount of ferric ion and by cementation reactions. Cementation and corrosion involve the same chemical processes. In this section, the maximum 
observed corrosion rates will be shown to be compatible with estimates of cementation rates on individual fluidized particles.

Fluidized beds are being used for the cementation of copper ${ }^{27}$ and selenium, ${ }^{35}$ and there is some information on cementation rates for fluidized particles ${ }^{36}$ from copper and nickel sulfate solutions. The cementation reaction rates are a function of ionic diffusion rates and are strongly influenced by the morphology of the deposited cement. The morphology is affected by the deposition conditions: temperature, solution concentration, and thickness of the deposit. ${ }^{37,38}$

Cements deposited from Salton Sea brines will have different characteristics, depending on the local environment. The results reported by Harrar et al. $^{32}$ give information about the morphology and composition of cements deposited from 20 - $h$ exposures to acidified, effluent $90^{\circ} \mathrm{C}$ brine. These cements were unusual in that no sulfur was detected on any of the steel surfaces examined, whereas sulfur was a component of all previously analyzed scales. An unexpected feature of the deposits was the presence of single crystals of lead carbonate. Analysis of the surface deposits, using energy dispersive $x$-ray spectrometry, showed the major constituents to be lead, chloride, and calcium, with smaller quantities of iron, copper, and potassium.

No information is available on diffusion rates for the species of interest in the brines. A value of about $1 \times 10^{-9} \mathrm{~m}^{2} / \mathrm{s}$ was estimated for the $\mathrm{M}^{++}$ ions in the brines. This value is based on the diffusivities at infinite dilution, ${ }^{39,40}$ together with estimates for the effects of the ionic strength of the solution and temperature. This estimate is probably good within a factor of two.

Using the above information, one can estimate cementation rates. For a $2-\mathrm{mm}$ particle fluidized in $100^{\circ} \mathrm{C}$ brine and the concentration of reducible species given in Table 2 for Magmamax No. 1 brine, the calculated corrosion rate is $\mathbf{1 . 8}$ $\mathrm{cm} / \mathrm{yr}(0.7 \mathrm{in} . / \mathrm{yr})$.

The observed corrosion rates vary with sample location, $\mathrm{pH}$, temperature, extent of scaling, etc. However, one might expect that the highest observed corrosion rates would obtain at the wellhead. A section of schedule 80, low carbon steel pipe from Magmamax No. 1 wellhead had been exposed intermittently (about $5000 \mathrm{~h}$ ) to twophase production fluid over a two-year period. The maximum corrosion was in a broad, 0.150 -in.-deep pit and translates to a corrosion rate of about $0.26 \mathrm{in} . / \mathrm{yr}^{41}$ Other observed corrosion rates are of the order of $80 \mathrm{mils} / \mathrm{yr}$ for mild steel corrosion coupons located near the wellhead. ${ }^{42}$

There are few measurements on acidified brines. The LLNL results ${ }^{39}$ at about $90^{\circ} \mathrm{C}$, using linear polarization techniques, indicated corrosion rates of about $100 \mathrm{mils} / \mathrm{yr}$ at a $\mathrm{pH}$ of 3.6 and 250 mils/yr at a pH of 2.3; however, the weight loss on the corrosion specimens indicated much lower weight losses, 9-36 mils per year.

The 15-day laboratory experiments with synthetic brines indicated that corrosion rates were independent of acid concentration for $\mathrm{pH}$ larger than about 3 . However, observed corrosion rates under those conditions were quite low, on the order of $20 \mathrm{mils} / \mathrm{yr}^{8}$ and the amounts of lead in solution were much larger than the amounts of iron dissolved. Possible reasons for the large differences in rates are poor mixing of the brine, leading to a diffusion-controlled process; a thin, semicoherent layer of cement forming, which impeded further cementation, etc.

\section{Comparison of Cementation with Alternative Processes}

As mentioned earlier, Salton Sea brines could be valuable minerals sources if economical processes were available that led to relatively pure "ores" for subsequent processing. Thus, one objective of process development should be separation of the minerals in the brine into "ores" easily amenable to subsequent processing.

Silica control and removal is a key part of any process for handling Salton Sea brines. In this context, LLNL experimental work on brine acidification, the effects of organic additives, and methods for precipitating, thickening, and filtering the silica needs to be considered in any future process design studies.

It is worthwhile comparing the proposed cementation process with previous process concepts. In all cases, most of the process is carried out on spent brines from the power plant. In the cementation process flow sheet (Fig. 7), finely divided iron is introduced into the brine at the wellhead to act as a nucleation source for sulfide precipitates and to recover precious metals. It is likely that silver would have to be periodically "mined" from the scales depositing on the piping if the wellhead brines were not so treated. Cementation fines might also decrease corrosion and scaling on the walls of process equipment, although careful 
plant design would be required to minimize erosion by the suspended solids. However, more information on the behavior of acidified wellhead brines is required before a final process flow sheet can be selected.

Electrolysis of the acidified brines will likely recover silver and other precious metals, lead, tin, etc. While the morphology of the deposits and diffusion rates for the ionic species would be the same as in the metal cementation process, electrolysis might be advantageous if the lead cement deposited from the brines is coherent and blocks access to the underlying iron surface. However, large electrode surface areas would be required, and it may be difficult to keep their surfaces relatively clean.

Sulfidation of acidified brine using hydrogen sulfide leads to good separation of silver, lead, and tin from zinc, iron, and manganese. However, it can only be carried out on post-flash brines since the $\mathrm{H}_{2} \mathrm{~S}$ would be separated from the brines in the power plant. The $\mathrm{H}_{2} \mathrm{~S}$ scavenging experiments of Quong et al., ${ }^{29}$ as well as the experiments at SRI, indicate that this might be a viable process. Sulfidation using sodium sulfide leads to a mixed precipitate containing iron and manganese, in addition to the desired elements. Separation of the minerals after recovery from the brines may be difficult. Handling of silica precipitation and contamination is another problem that has not been examined for either of the above sulfidation alternatives.

The combination of cementation (carried out either by reduction with metallic iron or electrolytically) with a somewhat modified Hazen flow sheet would have the following advantages:

- It would obtain good separation of $\mathrm{Ag}$, $\mathrm{Cu}, \mathrm{Pb}, \mathrm{Sn}$, etc. from the brines. If economically justified, the controlled potential electrolysis of acidified brine might allow for separation of the precious metals from lead, tin, and copper.

- The resulting silica, iron hydroxides, manganese, and zinc hydroxides will be uncontaminated by the other heavy elements. The concentrations of lead, tin, etc., still in solution after the cementation (Table 6) are lower than those expected from the manganese-hydroxide precipitation step (Table 5, stream 18) of the Hazen process.

- Thus the manganese and zinc mixed hydroxide product is likely to be quite pure. Separation of zinc from manganese in the fresh mixed hydroxides from precipitate is likely to be easy, although the difficulty experienced by the Bureau of Mines with aged precipitate is discouraging.
- If $78 \%$ ferromanganese alloy is a desired product, iron-manganese precipitation can probably be adjusted to obtain the desired iron/ manganese ratio.

- The process is designed to recover precious metals from wellhead brines.

- The individual process steps after cementation need not be carried out unless the economics are favorable. If manganese and zinc recovery are not required, and it is economically justifiable to produce the iron required for cementation locally, it might be possible to precipitate iron as goethite before silica removal and brine conditioning for reinjection.

\section{Elements of R\&D Program}

The main technical uncertainties in the proposed process have to do with the properties and composition of the cement and the proper design of the fluidized bed. The main uncertanties affecting the process economics are related to brine composition and precious metals recovery, although all aspects of the process would have to be optimized.

An R\&D program to validate the ideas presented above would consist of the following elements:

1. Preliminary studies

- Develop experimental plan in detail.

- Obtain reliable precious metals analyses of wellhead and spent brines from at least two wells in the area.

- Perform preliminary economic analysis, including some variants of the initial flow sheet, Fig. 7.

2. Laboratory cementation experiments (to be carried out primarily on acidified brines). Synthetic brines might be very useful for certain aspects of this portion of the program and are required for the laboratory fluidized-bed experiments.

- Verify equilibrium and transport data at $100^{\circ} \mathrm{C}$; estimate $200^{\circ} \mathrm{C}$ values. brines.

- Determine electrode potentials in acidified

- Determine physical characteristics of cement as a function of $\mathrm{pH}$ and cement layer thickness.

- Determine chemical composition of cement for several initial brine compositions.

- Determine effect on cement of scaling inhibitors other than $\mathrm{HCl}$. 

brine.

- Attempt goethite precipitation from spent

3. Laboratory fluidized-bed experiment. Equipment should be suitable for eventual operation in the field. However, laboratory experiments are likely to require closed-loop recirculation of synthetic brines, with provision for replenishing the metals recovered in the cementation process.

- Design objectives:

Design field experiment.

Design trace metal addition and control system.

Design on-line measurement and controls. Design or select commercial magnetic separator, thickeners, etc.

- Data obtained:

Operating characteristics of fluidized bed. Particle-size distribution of cement. in bed.

Equilibrium distribution of iron particles

Confirm transport and fluid-flow design parameters.

Operating characteristics of magnetic separator, thickeners, filters, etc.

4. Field experiments

- Design objectives: brine.

Confirm design parameters with real

Precious metals recovery from $200^{\circ} \mathrm{C}$ wellhead brines.

Iron consumption and ratio of metal to metal sulfide in product cement.

If goethite precipitation is successful in laboratory experiments, attempt with real brine. Erosion by fines.

\section{Acknowledgements}

I am particularly indebted to Jackson E. Harrar, who spent a great deal of time discussing the chemistry and problems in minerals recovery from brines. He suggested the idea of electrolysis of acidified brines and critically reviewed the drafts of this report. 


\section{References}

1. S. Mercado, J.A. Lopez, and R. Angulo, "Chemical Recovery as Alternative of Environmental Solution by Geothermal Brines in Cerro Prieto," Geothermal Resources Council, Transactions 3, 449 (1979).

2. L. Younker and P. Kasamayer, A Revised Estimate of Recoverable Thermal Energy in the Salton Sea Geothermal Resource Area, Lawrence Livermore National Laboratory, Livermore, Calif., UCRL-52450 (1978).

3. Mineral Commodity Summaries, 1981, U.S. Bureau of Mines, 1981.

4. S.C. Stinson, "Lithium Producers Gear Up for a Bright Future," Chem. Eng. News, October 26, 1981, p. 11.

5. J.E. Harrar, C.H. Otto, S.B. Deutscher, R.W. Ryon, and G.E. Tardiff, Studies of Brine Chemistry, Precipitation of Solids, and Scale Formation at the Salton Sea Geothermal Field, Lawrence Livermore National Laboratory, Livermore, Calif., UCRL-52640 (1979).

6. B.J. Skinner, D.E. White, W.H. Rose, and R.E. Mays, "Sulfides Associated with the Salton Sea Geothermal Brine," Econ. Geol. 62, 316-30 (1967).

7. R.N. Schock and A. Duba, The Effect of Electrical Potential on Scale Formation in Salton Sea Brine, Lawrence Livermore National Laboratory, Livermore, Calif,, UCRL-51944 (1975).

8. S.D. Cramer and J.P. Carter, Laboratory Corrosion Studies in Low and High Salinity Geobrines of the Imperial Valley, California, U.S. Bureau of Mines, Report of Investigations 8415 (1980).

9. S.R. Cosner and J.A. Apps, A Compilation of Data on Fluids from Geothermal Resources in the United States, Lawrence Berkeley Laboratory, Berkeley, Calif., LBL-5936 (1978).

10. A.L. Austin, A.W. Lundberg, L.B. Owen, and G.E. Tardiff, The LLL Geothermal Energy Program Status Report, January 1976-January 1977, Lawrence Livermore National Laboratory, Livermore, Calif., UCRL-50046-76 (1977).

11. J. Harrar and E. Raber, personal communication (1981).

12. E.P. Farley, E.L. Watson, D.D. MacDonald, R.W. Bartlett, and G.N. Krishnan, Recovery of Heavy Metals from High Salinity Geothermal Brine, SRI International, open file report at U.S. Bureau of Mines, Reno, Nevada (1980).

13. J.H. Hill and C.H. Otto, Jr., Sampling and Characterization of Suspended Solids in Brine from Magmamax No. 1 Well, Lawrence Livermore National Laboratory, Livermore, Calif., Preprint UCRL-87007 (1977).

14. R. Quong, F. Shoepflin, N.D. Stout, G.E. Tardiff, and F.R. McLain, "Processing Geothermal Brine Effluents for Injection," Geothermal Resources Council, Transactions 2, 551 (1978).

15. J.E. Harrar, L.E. Lorensen, C.H. Otto, S.B. Deutscher, and G.E. Tardiff, "Effects of Organic Additives on the Formation of Solids from Hypersaline Geothermal Brine," Geothermal Resources Council, Transactions 2, 259 (1978).

16. J.E. Harrar, F.E. Locke, C.H. Otto, L.E. Lorensen, S.B. Deutscher, W.P. Frey, and R. Lim, "Field Tests of Organic Additives for the Control of Scale at the Salton Sea Geothermal Field," Geothermal Resources Council, Transactions 3, 295 (1979).

17. L.B. Owen, E. Raber, C. Otto, R. Netherton, R. Neorath, and L. Allen, An Assessment of the Injectability of Conditioned Brine Produced by a Reaction Clarification, Lawrence Livermore National Laboratory, Livermore, Calif., UCID-18488 (1979).

18. E. Raber and R.E. Thompson, The Processing of High Salinity Brines for Subsurface Injection, Lawrence Livermore National Laboratory, Livermore, Calif., Preprint UCRL-83122, Rev. 2 (1980).

19. J.P. Carter and F.X. McCawley, "In Situ Corrosion Tests in Salton Sea Geothermal Brine Environments," J. Metals 30, 11-15 (1978).

20. H.H. Werner, "Contribution to the Mineral Extraction from Supersaturated Brines, Salton Sea Area, California," Geotherm. 2(2), 1651 (1970).

21. J. Barnea, "Geothermal Minerals-The Neglected Minerals," Geotherm. Energy Mag. 7(7), 12 (1979).

22. R.L Blake, Extracting Minerals from Geothermal Brines: A Literature Study, U.S. Bureau of Mines Information Circular 8638.

23. C.E. Berthold et al., Process Technology for Recovering Geothermal Brine Minerals, Hazen Research, Inc., for the U.S. Bureau of Mines, PB-241 867 (1974).

24. D.H. Christopher and M. Stewart, The Recovery and Separation of Mineral Values from Geothermal Brines, Hazen Research, Inc., for the U.S. Bureau of Mines, OFR 81-75 (1975). 
25. C.E. Berthold, Magmamax No. 1 Geothermal Minerals Recovery Pilot Plant, Engineering Design, open file report available at the U.S. Bureau of Mines, Geothermal Minerals Group, Reno Metallurgy Research Center (1978).

26. L. Schultze, U.S. Bureau of Mines, Reno, Nevada, private communications, March 10, 1981, and January 27, 1982.

27. E.A. Back, "Use of Particulate Iron in the Precipitation of Copper from Dilute Solutions," Trans. Soc. Min. Eng. 238, 12 (1967).

28. A.L. Austin and A.W. Lundberg, The LLL Geothermal Energy Program-Status Report on the Development of the Total Flow Concept, Lawrence Livermore National Laboratory, Livermore, Calif., UCRL-50046 (1978).

29. R. Quong, K.G. Knauss, N.D. Stout, and L.B. Owen, "An Effective $\mathrm{H}_{2} \mathrm{~S}$ Abatement Process Using Geothermal Brine Effluents," Geothermal Resources Council, Transactions 3, 557 (1979).

30. J. Harrar, personal communication, 1981; informal proposal to U.S. Bureau of Mines, 1979.

31. A.J. Bauman, personal communication, January 1981.

32. J.E. Harrar, J.W. Fischer, W.J. Beiriger, W.J. Steele, S.A. DiGiallonardo, and D.D. McCoy, "Incipient Processes in the Corrosion of Mild Steel in $90^{\circ} \mathrm{C}$ Hypersaline Geothermal Brine," Corr. Sci. 19, 819-833 (1979).

33. W. W. Walter, A Study of Fluidized Cathode Cementation, U.S. Bureau of Mines, BUMINES-OFR-40-79 (1978).

34. G. Thorsen, "Extractive Metallurgy of Copper," Topics in Nonferrous Extractive Metallurgy, R. Burkin, Ed. (Halsted Press, John Wiley \& Sons, New York, 1980).

35. P. Charles and P. Hannaert, "Fluid Bed Cementation of Se Contained in a Cu Electrolyte," in Proc. Extr. Met. Div. Symp. Cu Met., 1970 (American Institute of Metallurgical Engineers, 1970), p. 240.

36. N.A. Sayered-Dim and F. Lawson, "Cementation to Particulates," Trans. Inst. Min. Metall 85, 1-6, Sec. C (1975).

37. H. Majima, M. Mamiya, H. Tanaka, and K. Matsuda, "Physical Chemistry of Copppr Cementation," in World Mining and Metals Technology, Proc. Jt. MMIJ-AIME Mtg., 2, 567-84 (1976).

38. V. Annamalai and L.E. Murr, "Influence of Deposit Morphology on the Kinetics of Copper Cementation on Pure Iron," Hydromet. 4, 57-82 (1979).

39. J. E. Harrar, R. D. McCright, and A. Goldberg, Field Electrochemical Measurements of Corrosion Characteristics of Materials in Hypersaline Geothermal Brine, Lawrence Livermore National Laboratory, Livermore, Calif., UCRL-52376 (1977).

40. D. Miller, personal communication (1981).

41. H. Weiss, "Corrosion Evaluation of Magmamax No. 1 Production Pipe," LLL Geothermal Energy Development Program, L.B. Owen and G.E. Tardiff, Eds., ATHS/ISP-17 (1978), p. 84.

42. R. D. McCright, W. F. Frey, and G. E. Tardiff, "Localized Corrosion of Steels in Geothermal Steam/Brine Mixtures," Geothermal Resources Council, Transactions 4, 645 (1980). 